\title{
Meta-Analisis Miskonsepsi Siswa Mata Pelajaran IPA Materi Biologi Tingkat SMP
}

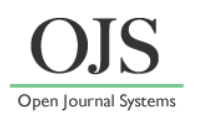

\author{
Melitha Aurora Hasanti ${ }^{*}$, Zulyusri \\ Prodi Pendidikan Biologi, Jurusan Biologi, FMIPA, Universitas Negeri Padang \\ Jl. Prof. Dr. Hamka Air Tawar Padang, Indonesia \\ *Email: melithaaurora@gmail.com
}

DOI: https://doi.org/10.33369/pendipa.6.1.263-268

\begin{abstract}
Misconception is an error in understanding a concept. This study aims to re-analyze students' misconceptions in the science subject matter of Biology at the junior high school level. This study uses a meta-analysis method. Meta-analysis is carried out by summarizing research results from several articles or online journals that have existed previously and are related to the research conducted. Data collection techniques by looking for existing articles or research journals that are relevant to the research. There were 4 research journals that were relevant to students' misconceptions in the IPA subject matter of Biology at the junior high school level. The results of the study found that in Biology subjects at the junior high school level: in Table 1, the highest misconceptions were found in the concept of cell organelles; in Table 2, the highest misconceptions are found in the material of the organization of life; in Table 3, the highest misconception is in question number 2 regarding gases released by plants during photosynthesis; in Table 4, the highest misconceptions occur in students with low scores. Based on these data, it is necessary for the teacher to analyze the misconceptions of students both low and high scores in order to minimize students' misconceptions in a learning material.
\end{abstract}

Keywords: Misconceptions, Biology material, IPA subjects in junior high school.

\begin{abstract}
ABSTRAK
Miskonsepsi adalah kesalahan dalam memahami suatu konsep. Penelitian ini bertujuan untuk menganalisis kembali miskonsepsi siswa pada pada mata pelajaran IPA materi Biologi tingkat SMP. Penelitian ini menggunakan metode meta-analisis. Meta analisis dilakukan dengan cara merangkum hasil penelitian dari beberapa artikel atau jurnal online yang sudah ada sebelumnya serta berkaitan dengan penelitian yang dilakukan. Teknik pengumpulan data dengan mencari artikel atau jurnal penelitian yang sudah ada yang relevan dengan penelitian. Ditemukan 4 jurnal penelitian yang relevan dengan miskonsepsi siswa pada mata pelajaran IPA materi Biologi tingkat SMP. Hasil penelitian ditemukan bahwa pada mata pelajaran IPA Biologi tingkat SMP: pada Tabel 1, miskonsepsi tertinggi terdapat pada konsep organel sel; pada Tabel 2, miskonsepsi tertinggi terdapat pada materi organisasi kehidupan; pada Table 3, miskonsepsi tertinggi terdapat pada soal nomor 2 mengenai gas yang dilepaskan tumbuhan saat fotosintesis; pada Tabel 4, miskonsepsi tertinggi terjadi pada siswa nilai rendah. Berdasarkan data tersebut, maka perlu bagi guru untuk menganalisis miskonsepsi siswa baik siswa nilai rendah maupun nilai tinggi agar meminimalisir adanya miskonsepsi siswa pada suatu materi pembelajaran.
\end{abstract}

Kata kunci: Miskonsepsi, materi Biologi, mata pelajaran IPA SMP.

\section{PENDAHULUAN}

Dalam pembelajaran, sangat penting bagi siswa untuk memahami suatu konsep. (Novitasari, 2016) menyatakan pentingnya memahami konsep merupakan modal untuk mendapatkan hasil belajar yang memuaskan pada akhir evaluasi. Jika hasil belajar siswa tidak memuaskan pada akhir evaluasi, kemungkinan 
ada yang salah pada pemahaman konsep siswa selama proses pembelajaran. Agar hal tersebut tidak terjadi, maka siswa tidak boleh salah memahami konsep atau dikenal dengan istilah miskonsepsi.

Miskonsepsi merupakan salah pemahaman terhadap suatu konsep yang telah disepakati oleh para ahli sehingga menimbulkan kekeliruan terhadap konsep itu sendiri. Menurut (Ibrahim, 2019), miskonsepsi adalah suatu keadaan seseorang yang memiliki konsepsi sendiri mengenai suatu konsep yang mana konsep tersebut berbeda dengan konsep yang telah disepakati oleh para ahli. Menurut (Eka, 2015), miskonsepsi merupakan konsep yang keliru.

Orang yang mengalami miskonsepsi dapat terlihat dari ciri tertentu. Menurut (Ibrahim, 2018), seseorang yang mengalami miskonsepsi ditandai dengan (1) berbedanya pengertian konsep seseorang tersebut dengan pengertian konsep yang disepakati oleh para ilmuwan; (2) seseorang tersebut sangat yakin bahwa pengertian konsepnya sendiri adalah benar; (3) karena sudah merasa yakin dengan pengetian konsepnya, maka seseorang tersebut akan bertahan dengan konsep yang dimilikinya dan akan sulit mengubah konsep seseorang tersebut. Ciri di atas dapat terjadi pada siapa saja, salah satunya terjadi pada siswa.

Miskonsepsi pada siswa dapat disebabkan oleh banyak faktor. Menurut (Ibrahim, 2019), miskonsepsi yang terjadi pada siswa biasanya dibentuk oleh siswa sendiri dan dipengaruhi oleh pengalaman dan lingkungan yang menyebabkan sering terjadi kesalahan pada diri siswa dalam memahami suatu konsep. Selain itu, menurut (Subrata, dkk., 2019), konsepsi awal (prakonsepsi) berbeda yang dimiliki siswa juga bisa menyebabkan terjadinya miskonsepsi pada siswa. Begitu juga menurut (Astuti, dkk., 2016), selain karena prakonsepsi awal siswa yang salah, miskonsepsi siswa juga disebabkan karena penalaran siswa belum lengkap, kemampuan memahami siswa masih rendah, dan juga disebabkan karena buku pegangan siswa untuk belajar (buku teks pelajaran). Karena berbagai penyebab itulah diperlukan suatu cara atau metode untuk mengidentifikasi miskonsepsi yang terjadi pada siswa.

Sampai saat ini masih terjadi miskonsepsi pada siswa. Agar miskonsepsi dapat diatasi, perlu dilakukan analisis untuk mengetahui miskonsepsi siswa serta siswa tidak tahu konsep atau paham terhadap konsep. Hal ini diperlukan karena menurut (Tayubi, 2005) antara siswa yang tidak tahu konsep dengan siswa yang mengalami miskonsepsi berbeda cara penanganannya. Maka, diperlukan suatu cara atau metode untuk mengidentifikasi miskonsepsi yang terjadi pada siswa, salah satunya dengan menggunakan metode CRI.

Metode CRI merupakan salah satu metode untuk identifikasi miskonsepsi siswa. Menurut (Irawan, 2020), CRI adalah cara pengukuran tingkat keyakinan seseorang dalam menjawab suatu pertanyaan. Menurut (Tayubi, 2005), skala CRI yang rendah menandakan responden tidak percaya diri dengan jawaban yang diberikan, sebaliknya skala CRI yang tinggi menandakan responden merasa yakin dengan jawaban yang diberikan. Jadi, tingkat keyakinan seseorang terhadap jawaban pertanyaan yang diberikan terlihat pada skala CRI.

Pada proses pembelajaran, miskonsepsi akan menjadi suatu masalah jika dibiarkan berlarut-larut. Menurut (Siswana, dkk., 2017), miskonsepsi bukan masalah sederhana karena miskonsepsi merupakan salah satu faktor yang dapat menghambat proses penerimaan pengetahuan. Menurut (Istighfarin, 2015), jika siswa mengalami miskonsepsi dari awal, maka guru akan mengalami kesulitan untuk mengubah konsep yang telah salah tersebut. Salah satu miskonsepsi siswa tejadi pada mata pelajaran IPA materi Biologi tingkat SMP. Agar miskonsepsi permasalahan miskonsepsi tidak berlarut-larut, maka diperlukan review dari berbagai penelitian mengenai analisis miskonsepsi siswa pada mata pelajaran IPA materi Biologi agar masalah miskonsepsi pada siswa dapat teratasi.

\section{METODE PENELITIAN}

Jenis penelitian yang digunakan adalah meta analisis. Meta analisis dilakukan dengan cara merangkum hasil penelitian dari beberapa artikel atau jurnal online yang sudah ada sebelumnya serta berkaitan dengan penelitian yang dilakukan. Kata kunci yang digunakan peneliti untuk menelusuri artikel atau jurnal terkait adalah miskonsepsi siswa mata pelajaran IPA materi Biologi. Dari beberapa penelusuran, ditemukan 
beberapa artikel jurnal yang mempunyai kaitan dengan analisis miskonsepsi miskonsepsi siswa mata pelajaran IPA materi Biologi. Teknik analisis yang digunakan adalah dengan metode pembanding untuk melihat miskonsepsi materi IPA pada buku teks. Analisis yang dilakukan dalam penelitian ini adalah membandingkan persentase miskonsepsi yang didapatkan dalam artikel jurnal tersebut.

\section{HASIL DAN PEMBAHASAN}

Analisis miskonsepsi siswa pada mata pelajaran IPA Biologi SMP telah banyak dilakukan oleh peneliti sebelumnya. Berikut data beberapa penelitian mengenai analisis miskonsepsi siswa pada mata pelajaran IPA materi Biologi.

Tabel 1. Persentase miskonsepsi siswa pada materi sistem organisasi kehidupan kelas VII SMP Negeri 14 Pontianak TA 2015/2016

\begin{tabular}{|c|c|c|c|}
\hline \multirow[b]{2}{*}{ Konsep } & \multicolumn{3}{|c|}{ Persentase (\%) } \\
\hline & Miskonsepsi & $\begin{array}{c}\text { Tahu } \\
\text { konsep }\end{array}$ & $\begin{array}{c}\text { Tidak } \\
\text { tahu } \\
\text { konsep }\end{array}$ \\
\hline $\begin{array}{l}\text { Sel } \\
\text { sebagai } \\
\text { unit } \\
\text { terkecil } \\
\text { kehidupan }\end{array}$ & 15,87 & 21,43 & 62,7 \\
\hline $\begin{array}{l}\text { Struktur } \\
\text { dan fungsi } \\
\text { sel }\end{array}$ & 23,81 & 22,61 & 53,57 \\
\hline $\begin{array}{l}\text { Macam- } \\
\text { macam } \\
\text { organel } \\
\text { sel }\end{array}$ & 28,57 & 22,03 & 49,4 \\
\hline
\end{tabular}

Sumber: (Subrata, dkk., 2019)

Berdasarkan Tabel 1 terlihat bahwa persentase miskonsepsi siswa tertinggi terdapat pada konsep macam-macam organel sel sebesar $28,57 \%$. Hal ini diduga terjadi karena materi sel pertama kali dipelajari saat kelas VII. Karena pada kelas VII siswa baru mulai mempelajari dan mengenal macam-macam organel sel, maka siswa belum terlalu mengenal organel-organel sel. (Rafika, dkk., 2015) menyatakan siswa yang tidak familiar dengan submateri organel sel disebabkan karena keterbatasan informasi yang dimiliki siswa selama mempelajari organelorganel sel tersebut.

Dari Tabel 1 terlihat bahwa persentase siswa tahu konsep tertinggi terdapat pada konsep struktur dan fungsi sel sebesar $22,61 \%$. Diketahui bahwa perbandingan persentase tahu konsep antara tiga konsep yang dijabarkan di tabel tidak jauh berbeda. Persentase siswa tahu konsep pada konsep struktur dan fungsi sel lebih tinggi dibanding dua konsep lainnya, maka diduga karena tingkat pemahaman konsep siswa pada konsep struktur dan fungsi sel cukup tinggi dibanding dua konsep lainnya. Menurut (Ibrahim, 2018), pemahaman siswa terhadap suatu konsep dimaknai sebagai siswa sudah mengetahui konsepnya dan dapat mengidentifikasi sendiri konsep yang ada. Jadi, tingginya persentase tahu konsep siswa pada konsep struktur dan fungsi sel disebabkan karena siswa telah mempelajari konsepnya dan bisa mengolah dengan baik konsep struktur dan fungsi sel.

Dari Tabel 1 juga terlihat bahwa persentase siswa tidak tahu konsep tertinggi terdapat pada konsep sel sebagai unit terkecil kehidupan sebesar $62,7 \%$. Penyebab tingginya persentase siswa tidak tahu konsep pada konsep sel sebagai unit terkecil kehidupan diduga karena siswa tidak mempelajari dan tidak memahami konsep sel sebagai unit terkecil kehidupan. Hal tersebut dapat disebabkan karena siswa tidak tertarik untuk mengetahui konsep sel sebagai unit terkecil kehidupan sehingga dapat berpengaruh terhadap pemahaman konsep siswa. Menurut (Afifah \& Asri, 2020), kesulitan serta ketidaktertarikan siswa mempelajari suatu materi dapat mempengaruhi pemahaman konsep siswa.

Tabel 2. Persentase pemahaman siswa pada materi ciri makhluk hidup dan organisasi kehidupan di SMPN 4 Penukal Utara

\begin{tabular}{|c|c|c|c|}
\hline \multirow[b]{2}{*}{ Materi } & \multicolumn{3}{|c|}{ Persentase $(\%)$} \\
\hline & Miskonsepsi & $\begin{array}{l}\text { Paham } \\
\text { konsep }\end{array}$ & $\begin{array}{r}\text { Tidak } \\
\text { paham } \\
\text { konsep }\end{array}$ \\
\hline $\begin{array}{l}\text { Ciri-ciri } \\
\text { Makhluk } \\
\text { Hidup }\end{array}$ & 41,5 & 30 & 28,4 \\
\hline $\begin{array}{l}\text { Organisasi } \\
\text { Kehidupan }\end{array}$ & 48 & 19 & 32,1 \\
\hline
\end{tabular}


Berdasarkan Tabel 2 dapat dilihat bahwa persentase miskonsepsi siswa tertinggi terdapat pada materi organisasi kehidupan $(48 \%)$. Hal ini diduga karena materi organisasi kehidupan merupakan materi yang cukup kompleks sehingga siswa membutuhkan usaha untuk memahami materi yang menyangkut sistem organisasi kehidupan, seperti sel dan jaringan serta banyak istilah-istilah terkait materi yang masih asing bagi siswa. Menurut (Puspitasari, dkk., 2019) miskonsepsi dapat disebabkan karena istilah asing yang sulit dipahami serta kerumitan suatu konsep atau materi disebabkan karena kompleksitas materi atau konsep tersebut. Begitu juga menurut (Duda, dkk., 2020) banyak istilahistilah asing dengan bahasa yang sulit dapat menjadi penyebab miskonsepsi siswa.

Dari Tabel 2 terlihat bahwa persentase siswa paham konsep tertinggi terdapat pada materi ciriciri makhluk hidup (30\%). Penyebab tingginya persentase paham konsep siswa pada materi ciri makhluk hidup diduga karena materi ini dekat dengan kehidupan sehari-hari siswa sehingga siswa dapat memahami dan mengerti konsepkonsep yang terkait dengan ciri-ciri yang terdapat pada makhluk hidup. Menurut (Ibrahim, 2018), pemahaman siswa terhadap suatu konsep dimaknai sebagai siswa sudah mengetahui konsepnya dan dapat mengidentifikasi sendiri konsep yaang ada. Artinya, siswa dapat memahami dan mengolah informasi konsep yang terkait ciri-ciri makhluk hidup.

Dari Tabel 2 terlihat juga bahwa persentase siswa tidak paham konsep tertinggi terdapat pada materi organisasi kehidupan $(32,1 \%)$. Sama halnya dengan penyebab miskonsepsi di atas, karena materi sistem organisasi kehidupan merupakan materi yang cukup kompleks, maka diduga siswa merasa cukup kesulitan untuk memahami materi seputar sistem organisasi kehidupan, bahkan mungkin juga terdapat siswa yang tidak tertarik mempelajari materi sistem organisasi kehidupan. Menurut (Afifah \& Asri, 2020), kesulitan serta ketidaktertarikan siswa mempelajari suatu materi dapat mempengaruhi pemahaman konsep siswa.

Berdasarkan Tabel 3 dapat dilihat bahwa persentase miskonsepsi siswa tertinggi pada materi fotosintesis terdapat pada soal nomor 2 sebesar 50\%. Soal nomor 2 merupakan pertanyaan mengenai gas yang dilepaskan tumbuhan saat fotosintesis. Berdasarkan soal nomor 2, diketahui bahwa selain gas dilepaskan saat fotosintesis, terdapat juga gas yang diterima saat fotosintesis. Keterbalikan memahami konsep antara gas yang dilepaskan dan diterima saat proses fotosintesis diduga dapat menyebabkan terjadinya miskonsepsi pada siswa. Menurut (Pradina \& Yuliani, 2020), siswa sering terbalik memahami suatu materi sehingga menyebabkan terjadi miskonsepsi meskipun guru telah memberikan penjelasan mengenai materi dan materi juga terdapat pada buku teks pelajaran.

Tabel 3. Persentase miskonsepsi siswa kelas VII di SMP Negeri 2 Tana Tidung pada konsep

Fotosintesis

\begin{tabular}{c|c|c|c}
\hline \multirow{2}{*}{$\begin{array}{c}\text { Nomor } \\
\text { Soal }\end{array}$} & \multicolumn{3}{c}{ Persentase (\%) } \\
\cline { 2 - 4 } & Miskonsepsi & $\begin{array}{c}\text { Paham } \\
\text { konsep }\end{array}$ & $\begin{array}{c}\text { Tidak } \\
\text { tahu } \\
\text { konsep }\end{array}$ \\
\hline 1 & 32,14 & 50 & 10,71 \\
2 & 50 & 17,85 & 21,43 \\
3 & 35,71 & 39,28 & 14,28 \\
4 & 42,86 & 28,57 & 21,43 \\
5 & 28,57 & 28,57 & 21,43 \\
6 & 28,57 & 39,28 & 21,43 \\
7 & 39,28 & 35,71 & 25 \\
\hline
\end{tabular}

Sumber: (Yanti, dkk., 2019)

Dari Tabel 3 juga memperlihatkan persentase siswa paham konsep tertinggi pada materi fotosintesis terdapat pada soal nomor 1 sebesar 50\%. Soal nomor 1 merupakan pertanyaan mengenai fungsi dan posisi letak klorofil pada tumbuhan. Hal ini diduga karena siswa bisa memahami dan mengolah konsepkonsep terkait fungsi dan posisi letak klorofil tumbuhan yang diterimanya baik dari guru maupun dari buku. Menurut (Pradina \& Yuliani, 2020), siswa yang memahami konsep menunjukkan bahwa siswa mampu mengolah konsep yang diterimanya selama proses pembelajaran.

Dari Tabel 3 juga terlihat bahwa persentase siswa tidak paham konsep tertinggi pada materi fotosintesis terdapat pada soal nomor 7 sebesar $25 \%$. Soal nomor 7 adalah soal yang membahas mengenai gas yang diambil saat ada cahaya matahari pada peristiwa fotosintesis. Penyebab tingginya persentase siswa tidak paham konsep pada soal yang membahas gas yang diambil saat 
ada cahaya matahari pada peristiwa fotosintesis diduga karena siswa tidak yakin dengan jawaban mengenai gas yang diambil saat ada cahaya matahari pada peristiwa fotosintesis. Menurut (Pradina \& Yuliani, 2020), tidak yakin dengan pilihan jawaban menandakan bahwa siswa kurang memahami materi yang dipelajarinya.

Tabel 4. Persentase miskonsepsi siswa SMP

Negeri 46 Palembang pada materi sistem peredaran darah manusia

\begin{tabular}{|c|c|c|c|}
\hline \multirow[b]{2}{*}{ Kelas } & \multicolumn{3}{|c|}{ Persentase (\%) } \\
\hline & Miskonsepsi & $\begin{array}{l}\text { Paham } \\
\text { konsep }\end{array}$ & $\begin{array}{c}\text { Tidak } \\
\text { tahu } \\
\text { konsep }\end{array}$ \\
\hline $\begin{array}{l}\text { Siswa } \\
\text { nilai } \\
\text { tinggi } \\
\text { (VIII.7) }\end{array}$ & 28 & 42 & 6 \\
\hline $\begin{array}{l}\text { Siswa } \\
\text { nilai } \\
\text { sedang } \\
\text { (VIII.8) }\end{array}$ & 28 & 43 & 4 \\
\hline $\begin{array}{l}\text { Siswa } \\
\text { nilai } \\
\text { rendah } \\
\text { (VIII.5) }\end{array}$ & 32 & 42 & 4 \\
\hline
\end{tabular}

Sumber: (Alfiontari, dkk., 2019)

Berdasarkan Tabel 4 terlihat bahwa persentase miskonsepsi siswa tertinggi pada materi sistem peredaran darah terdapat pada siswa nilai rendah (VIII.5) sebesar 32\%. Diduga pada siswa dengan nilai rendah memiliki tingkat pemahaman konsep pada materi sistem peredaran rendah yang cukup rendah, sehingga menyebabkan siswa mengalami miskonsepsi pada materi tersebut. Menurut (Adhani \& Rupa, 2020), akibat dari rendahnya pemahaman konsep pada siswa adalah dapat menyebabkan terjadinya miskonsepsi bahkan tidak paham konsep.

Dari Tabel 4 juga terlihat bahwa persentase siswa paham konsep tertinggi pada materi sistem peredaran darah terdapat pada siswa kelas sedang (VIII.8) sebesar 43\%. Diduga pada siswa dengan nilai sedang merupakan siswa yang berusaha untuk setingkat dengan siswa nilai tinggi dengan berusaha memahami dan mengolah konsepkonsep yang dipelajarinya, sehingga siswa dapat memahami konsep yang dipelajari tersebut. Menurut (Pradina \& Yuliani, 2020), siswa yang memahami konsep menunjukkan bahwa siswa mampu mengolah konsep yang diterimanya selama proses pembelajaran.

Dari Tabel 4 juga terlihat bahwa persentase siswa tidak paham konsep tertinggi pada materi sistem peredaran darah terdapat pada siswa kelas nilai tinggi (VIII.7) sebesar 6\%. Persentase kategori ini tergolong rendah, artinya hanya sedikit konsep yang mengalami tidak paham konsep. Diduga penyebab siswa nilai tinggi tidak memahami konsep adalah tingginya rasa percaya diri siswa terhadap konsep yang dimilikinya, walaupun konsep tersebut salah. Menurut (Salirawati, 2012), sifat terlalu percaya diri diharapkan tidak ada dalam diri siswa karena dapat memunculkan sifat yang tidak diinginkan serta siswa tidak selamanya mengetahui segala hal.

\section{KESIMPULAN}

Meta-analisis mengenai analisis miskonsepsi siswa pada mata pelajaran IPA Biologi tingkat SMP telah dilakukan. Berdasarkan empat tabel mengenai analisis miskonsepsi siswa pada mata pelajaran IPA Biologi tingkat SMP, hasil meta-analisis menujukkan bahwa pada mata pelajaran IPA Biologi tingkat SMP, semua materi yang dianalisis mengalami miskonsepsi pada siswa. Pada Tabel 1, miskonsepsi tertinggi terdapat pada konsep organel sel. Pada Tabel 2, miskonsepsi tertinggi terdapat pada materi organisasi kehidupan. Pada Table 3, miskonsepsi tertinggi terdapat pada soal nomor 2 mengenai gas yang dilepaskan tumbuhan saat fotosintesis. Pada Tabel 4, miskonsepsi tertinggi terjadi pada siswa nilai rendah. Berdasarkan data tersebut, maka perlu bagi guru untuk menganalisis miskonsepsi siswa baik siswa nilai rendah maupun nilai tinggi agar meminimalisir adanya miskonsepsi siswa pada suatu materi pembelajaran.

\section{DAFTAR PUSTAKA}

Adhani, A., \& Rupa, D. (2020). Analisis Pemahaman Konsep Mahasiswa Pendidikan Biologi pada Matakuliah Fisiologi Tumbuhan. QUANTUM: Jurnal Inovasi Pendidikan Sains, 11 (1): 18-26. 
Afifah, Y. N., \& Asri, M. T. (2020). Profil Miskonsepsi Siswa pada Submateri Struktur dan Fungsi Sel Menggunakan Four Tier Test. BioEdu: Berkala Ilmiah Pendidikan Biologi, 9 (3): 390-396.

Alfionitari, E., Nurlaeli, N., \& Afriansyah, D. (2019). Identifikasi Miskonsepsi Siswa dengan Menggunakan Metode Certainty of Response Index (CRI) pada Materi Pelajaran IPA. (JPB) Jurnal Pembelajaran Biologi: Kajian Biologi dan Pembelajarannya, 6 (1): 22-30.

Astuti, F., Redjeki, T., \& Nurhayati, N. D. (2016). Identifikasi Miskonsepsi dan Penyebabnya pada Siswa Kelas XI MIA SMA Negeri 1 Sukoharjo Tahun Pelajaran 2015/2016 pada Materi Pokok Stoikiometri. Jurnal Pendidikan Kimia (JPK), 5 (2): 1017.

Duda, H. J., Wahyuni, R. E., \& Setyawan, A. E. (2020). Mengidentifikasi Miskonsepsi Mahaasiswa Pendidikan Biologi pada Konsep Bioteknologi Hewan. BIOEDUSCIENCE, 04 (01): 97-105.

Eka, K. I. (2015). Miskonsepsi dalam Pelajaran IPA di Sekolah Dasar: Tinjauan Kritis dari Sudut Ilmu Pengetahuan Edisi 1. Yogyakarta: Deepublish.

Ibrahim, M. (2018). Perubahan Konsepsi IPA. Sidoarjo: Zifatama Jawara.

Ibrahim, M. (2019). Model Pembelajaran P2OC2R untuk Mengubah Konsepsi IPA Siswa. Sidoarjo: Zifatama Jawara.

Irawan, E. (2020). Deteksi Miskonsepsi di Era Pandemi. Sleman: Zahir Publishing.

Istighfarin, L. (2015). Profil Miskonsepsi Siswa pada Materi Struktur dan Fungsi Jaringan Tumbuhan. BioEdu, 4 (3): 991-995.

Novitasari, D. (2016). Pengaruh Penggunaan Multimedia Interkatif terhadap Kemampuan Pemahaman Konsep Matematis Siswa. Jurnal Pendidikan Matematika \& Matematika, 2 (2): 8-18.

Pradina, L. E., \& Yuliani, Y. (2020). Profil Miskonsepsi Siswa pada Materi Pertumbuhan dan Perkembangan Tumbuhan Menggunakan Three-Tier Multiple Choice Test. BioEdu: Berkala Ilmiah Pendidikan Biologi, 9 (1): 310-318.
Puspitasari, Y., Reza, S. P., Bachtiar, Y., \& Prayitno, B. A. (2019). Identifikasi Miskonsepsi Materi Jaringan Tumbuhan pada Mahasiswa Pendidikan Biologi di Salah Satu Universitas di Surakarta. BIOEDUKASI Jurnal Pendidikan Biologi, 10 (2): 171-178.

Rafika, A., Rachmadiarti, F., \& Isnawati, I. (2015). Identifikasi Miskonsepsi Siswa pada Subtopik Struktur dan Fungsi Organel Sel Mneggunakan Instrumen CRI dan Wawancara Diagnostik. BioEdu: Berkala Ilmiah pendidikan Biologi, 4 (2): 908-912.

Salirawati, D. (2012). Percaya Diri, Keingintahuan, dan Berjiwa Wirausaha: Tiga Karakter Penting Bagi Peserta Didik. Jurnal Pendidikan Karakter, II (2): 213224.

Samiha, Y. T., Agusta, E., \& Rolahnoviza, G. (2017). Analisis Miskonsepsi Siswa pada Mata Pelajaran IPA di SMPN 4 Penukal Utara Kabupaten Penukal Abab Lematang Ilir Pendopo. Bioilmi, 3 (1): 38-46.

Siswana, R., Armen, A., \& Helendra, H. (2017). Identifikasi Miskonsepsi Materi Fotosintesis pada Siswa Kelas IX SMPN 7 Padang Menggunakan Tes Diagnostik Two Tier Multiple Choice. Jurnal Biosains, 1 (2): 277-284.

Subrata, Y., Kurniawan, A. D., \& Qurbaniah, M. (2019). Analisis Miskonsepsi Siswa pada Materi Sistem Organisasi Kehidupan Kelas VII SMP Negeri 14 Pontianak. Pena Kreatif: Jurnal Pendidikan, 8 (2): 125-142.

Tayubi, R. Y. (2005). Identifikasi Miskonsepsi pada Konsep-Konsep Fisika Menggunakan Certainty of Response Index (CRI). Mimbar Pendidikan, 3 (XXIV): 4-9. 